\title{
Maternal-Fetal Hepatitis E Transmission: Is It Underestimated?
}

\author{
Maysaa El Sayed Zaki ${ }^{1}$, Mohammed Magdy Abd El Razek ${ }^{2}$ and Hassan Magdy Abd El Razek ${ }^{1}$ \\ ${ }^{1}$ Clinical Pathology, Mansoura Faculty of Medicine, Egypt; ${ }^{2}$ Mansoura University Hospital, Egypt
}

\begin{abstract}
Hepatitis E virus (HEV) is an enterically transmitted virus; and several modes of transmission have been proposed, including blood transfusion, person to person transmission, and transplacental transmission. HEV during pregnancy is associated with an unfavorable prognosis for mothers and in severe cases can cause acute fulminate hepatitis and death. Transplacental transmission of HEV usually results in unfavorable outcomes of pregnancy, mainly fetal loss, preterm labor, and hepatic dysfunction in neonates. In this review, we will summarize the effects of HEV on maternal-fetal health in various clinical situations.

(C) 2014 The Second Affiliated Hospital of Chongqing Medical University. Published by XIA \& HE Publishing Ltd. All rights reserved.
\end{abstract}

\section{Introduction}

Hepatitis E virus (HEV) is a small RNA virus responsible for hepatitis E. HEV is a spherical, non-enveloped, single stranded, positive-sense $5^{\prime}$-capped RNA of $7.2 \mathrm{~kb}$. It consists of short $5^{\prime}$ and $3^{\prime}$ untranslated regions (UTRs) and three partially overlapping open reading frames (ORF) called ORF1, ORF2, and ORF3. ${ }^{1}$ There are five known major genotypes of $\mathrm{HEV}$, and they differ according to geographical distribution. Genotype I includes Asian (India, Burma, Nepal, ChinaXinjiang, Pakistan) strains ${ }^{2-8}$ and African (Chad, Algeria, Tunisia, Morocco, Egypt, Namibia) strains, ${ }^{9-12}$ genotype II includes US and Japanese strains, ${ }^{13}$ genotype III includes Mexican and African (Nigeria) strains, ${ }^{14,15}$ genotype IV (4) includes Chinese (Shanga) and Japanese strains, ${ }^{13}$ and genotype $V(5)$ includes European strains. ${ }^{14,15}$ The disease is endemic in large parts of developing countries in Asia, Africa, and Latin America. ${ }^{16}$

Contamination of drinking water is the most common mode for the spread of HEV. Studies indicate that hepatitis $E$ may be a zoonotic disease with pigs and rats serving as reservoirs for human infection. ${ }^{17}$ Person-to-person transmission of HEV between family members has been documented

\footnotetext{
Keywords: Hepatitis E virus; Vertical transmission; Prevention.

Abbreviations: ALF, acute liver failure; AVH, acute viral hepatitis; CDC, Center for Disease Control; FDA, Food and Drug Administration; FHF, fulminant hepatic failure; HBV, hepatitis B virus; HEV, hepatitis E virus; Ig, immunoglobulin; ORF, open reading frame; UTR, untranslated region.

Received: 28 January 2014; Revised: 3 March 2014; Accepted: 6 March 2014

DOI of original article: 10.14218/JCTH.2014.00006.

Correspondence to: Maysaa El SayedZaki, Clinical Pathology, Mansoura Faculty of Medicine, El Gomhoria street, Mansoura 35516, Egypt. Tel: +20-502258877, Fax:+20-502247042, Email:may_s65@hotmail.com
}

in only $1 \%$ to $2 \%$ of cases, whereas for person-to-person transmission in hepatitis Ait is $15 \% .{ }^{18}$ Transplacental transmission of HEV in the third trimester of pregnancy has been described; and in affected newborns it is associated with a high perinatal mortality. ${ }^{19,20}$

HEV is considered an enterically transmitted self-limiting acute viral hepatitis. It also has been reported to cause acute viral hepatitis, especially among travelers to endemic areas, and to cause a small percentage of sporadic fulminant hepatic failure (FHF) in persons without history of travel to endemic areas. Overall, serological studies highlight a global distribution of this virus. ${ }^{16}$

\section{Hepatitis E in pregnancy}

The course of Hepatitis $E$ in pregnancy is different than the mild self constraining infection described in other populations. Hepatitis $\mathrm{E}$ has both a high prevalence and rigorous course in pregnant women in some geographic regions of HEV endemic countries, such as Northern India. ${ }^{21,22}$ However, in Egypt, an HEV endemic country, it has been shown to have a benign course with little or no morbidity. ${ }^{23}$ Similar findings were shown in pregnant women in western countries, where they suffer less morbidity and mortality. HEV infection during pregnancy could result in rigorous complications, which may lead to fetal and/or maternal mortality, abortion, premature distribution, or death of a live-born baby soon after birth. The severity of the complications depends on the rigor of the infection, stratified as acute viral hepatitis $(\mathrm{AVH})$ or acute liver failure (ALF). ${ }^{24,25}$

In a large-scale prospective study from Northern India on maternal and fetal outcomes of HEV, approximately $60 \%$ of viral hepatitis in pregnant women was due to HEV infection. Moreover, FHF was more likely among HEV-infected women $(55 \%)$, who were at 2.7 time's greater risk than non-HEV infected women (20\%). Maternal mortality secondary to FHF was higher in the HEV infected group (41\%) compared to the non-HEV group (7\%). ${ }^{22}$

In addition, sporadic HEV infection is associated with incremented incidence and astringency in pregnant women. HEV alone contributed to a subset of patients with acute viral hepatitis all over the world. Importantly, prevalence and the astringency of HEV infection in pregnant women did not differ significantly in various stages of gestation. ${ }^{26}$ However, it was reported that high mortality was associated with infection in the third trimester. ${ }^{26}$ In one case of second trimester ascites due to fetal HEV infection, the ascites resolved in utero, and healthy infant was born at 38 weeks of gestation. 27,28

Incremented maternal and fetal mortality has been reported by many groups, mainly from developing countries. 
Poor prenatal care and maternal nutrition appear to have contributed significantly to the incremented astringency of infection in these countries. ${ }^{29}$

In Egypt, where prevalence of anti-HEV in rural communities is very high, rigorous HEV-caused AVH in pregnant women has not been reported. In one study, the anti-HEV prevalence in a series of pregnant women was $84 \%$, with no evidence for $\mathrm{AVH} .{ }^{30}$ The differences in the outcome of HEV in different geographical areas could be the result of early childhood immunity acquired from HEV exposures that may modify subsequent exposure to the virus. Alternatively, the predominant HEV genotypes in Egypt may be less virulent than those in Asia. ${ }^{30,31}$ The studies from developed countries differ over maternal-fetal outcomes of pregnancy associated with viral hepatitis. The pregnancy state associated with hepatitis $\mathrm{E}$ has not been linked to rigorous course with adequate nutrition. This is in contrast to the clinical course of hepatitis B virus (HBV) infection acquired perinatally by neonates. This is likely due to the different pathogenic effects of both viruses. Liver injury is caused by immune replication of the host against the pathogen in hepatitis $\mathrm{B}^{32}$ whereas liver injury in HEV is related to direct cytopathogenic alterations in liver cells. ${ }^{33}$

There is a relationship between HEV genotype and the unpropitious effects of HEV infection in pregnancy. Hepatitis $E$ caused by HEV genotype 1 has consistently been observed to engender these negative effects in pregnancy. Although HEV genotype 2 was implicated in acute liver failure in a pregnant woman during an outbreak in Namibia, ${ }^{34}$ the potential of genotypes 2-4 to cause adverse outcomes in pregnant women, given exposure, remains controversial.

\section{Hepatitis E vertical transmission}

There is emerging concerns from epidemiologic and clinical studies suggesting that vertical transmission of HEV may occur frequently from infected mothers and contribute to poor perinatal health outcomes in addition to the effects of maternal morbidity and mortality. ${ }^{34}$

The risk of vertical transmission of HEV infection from mother to infant was $100 \%$ in an antecedent study of a series of pregnant women. There may, however, have been selection errors. The babies born to mothers with active disease either were either preterm or had anicteric hepatitis. This high transmission rate denotes the importance of vertical transmission of HEV infection. ${ }^{35}$ In another study, vertical transmission of HEV was in 33\% of newborns born to infected women in the third trimester of pregnancy. HEV infection was determined with detection of HEV-RNA or immunoglobulin (Ig)M anti-HEV antibodies. ${ }^{36,37}$

Vertically transmitted HEV infection is known to cause acute hepatitis in neonates, but the clinical course and duration of viremia is unclear. ${ }^{38} \mathrm{HEV}$ in neonates is selfconstraining and does not run a chronic or prolonged clinical course. This finding is consistent with another study by Khuroo et al., 2009 that found HEV-infected neonates at birth survived when the infection cleared. ${ }^{38}$ The clinical profile of HEV infected babies customarily varies from elevated liver enzymes alone, elevated bilirubin alone, and combination elevated bilirubin and elevated liver enzymes. Elevated bilirubin (unconjugated) could be due to physiological jaundice, which occurs in neonates. However, a pattern of serum bilirubin (commixed pattern) identified in three babies from this study was inconsistent with physiological jaundice and more consistent with an HEV infection. Nevertheless, fatal outcomes were seen in other studies. Newborn babies of infected mothers developed a syndrome of fatal FHF, and this syndrome occurred in some babies with anicteric hepatitis. ${ }^{20,22}$ We could not find any reports of assiduous HEV infection in infants born to mothers with hepatitis $\mathrm{E}$. This is consistent with the natural history of hepatitis $E$ infection in adults, where, by convention, it occurs in a self-circumscribing pattern. ${ }^{39}$ Although chronic HEV infections have been reported primarily in immunosuppressed and immunocompromised populations, ${ }^{39-57}$ there are no reports of chronic HEV infection in pregnant women or infants. Theoretically, among immunocompromised pregnant women or neonates, such infections could occur. Pregnant women may be coinfected with other hepatotropic pathogens, ${ }^{58-65}$ but how such coinfections influence vertical HEV transmission and outcomes has not yet been studied. The astringency of HEV infection in the mother and baby may be linked. Findings from an anterior study suggested that fetal disease influenced the course of maternal HEV infection and provided a clear relationship between FHF of the fetus and mother. ${ }^{54}$ Tables 1 and 2 summarize the different incidence of HEV infection in pregnancy and vertical transmission.

\section{Pathogenesis of hepatitis E in pregnancy}

Diminished cellular immunity, manifested by decreased CD4, increased $C D 8$, and reduced $C D 4 / C D 8$ ratio, may be the leading cause of astringency of HEV infection during pregnancy. ${ }^{65}$ Moreover, increased levels of steroid that influence viral replication and expression may cause the rigor of HEV infection. Steroid hormones are immunosuppressive and mediate lymphocyte apoptosis through NF- $\mathrm{BB}$. NF- $\kappa \mathrm{B}$ is a dimeric transcription factor that has varied roles in liver development, liver regeneration, and immune replication. ${ }^{28}$ When HEV infection occurs, a cytotoxic immune replication (Th1) may be elicited in Th2 partial pregnant women. FHF is always associated with high HEV viral load, leading to vigorous Th1 replication. If this elevated Th1 immune replication remains inadequate to control a high viral load, it is possible that Th1 replication will increase but that cytotoxic immune replication may result in reduced fetal defenses and eventually fetal death. ${ }^{29}$

It has been theorized that fetal infection in the uterus may itself leads to adverse maternal outcomes. ${ }^{54}$ Such upsidedown vertical effects have been posited to occur with other viral infections as well in animal models. ${ }^{66}$ For example, it was demonstrated in a murine model of herpes infection that fetal inflammatory replications to viral replication in the placenta may predispose the mother to morbidity and reduce the mother's capacity for sustaining the pregnancy. ${ }^{67,68} \mathrm{~A}$ prior study highlighted that hormone receptor mitigated inflammatory replications at the fetomaternal interface could affect pregnancy outcomes in human hepatitis E. ${ }^{69}$ Fig. 1 summarizes the outcome of HEV infection during pregnancy associated with different immune responses and HEV genotypes.

\section{Laboratory diagnosis of hepatitis E}

During acute HEV infection, serological studies showed that anti-HEV IgM becomes detectable days before the onset of symptoms and vanishes over a 4-6 month period. ${ }^{70}$ AntiHEVIgG appears soon after the IgM replication and may persist for up to 12 years after infection. ${ }^{71} \mathrm{Fig} .2$ summarizes 
Zaki M.E. et al.: Hepatitis E, pregnancy

Table 1. Incidence of HEV infection in pregnancy and its consequences

\begin{tabular}{|c|c|c|c|}
\hline & HEV pregnancy incidence & Severity & Mortality \\
\hline Patra et al., ${ }^{23}$ 2007-India & $\begin{array}{l}\text { Among } 200 \text { pregnant women } \\
\text { screened for HEV, } 60 \% \text { of } \\
\text { them had positive markers } \\
\text { for HEV. }\end{array}$ & $\begin{array}{l}\text {-Fulminant hepatic failure } \\
\text { (FHF) } \\
\text {-Obstetric complications } \\
\text { weremore common, such } \\
\text { as antepartum hemorrhage, } \\
\text { intrauterine fetal death, } \\
\text { and preterm delivery }\end{array}$ & $\begin{array}{l}\text { Maternal mortality was greater } \\
\text { (relative risk, } 6.0 \text { [CI, } 2.7 \text { to } \\
13.3] ; \mathrm{P}<0.001 \text { ) }\end{array}$ \\
\hline Stoszek et al., ${ }^{31} 2006$-Egypt & $\begin{array}{l}\text { Anti-HEV screening among } \\
2,428 \text { women was } 84 \%\end{array}$ & No clinical disease & No mortality \\
\hline Khuroo\&Kamili, ${ }^{39}$ 2009-India & HEV in $205(49.6 \%)$ & $\begin{array}{l}\text { FHF, cerebral edema, and dis- } \\
\text { seminated intravascular coagu- } \\
\text { lation }\end{array}$ & $\begin{array}{l}\text { FHF died [25 }(53.2 \%) \text { pregnant } \\
\text { - women and } 25(69.5 \%) \text { non- } \\
\text { pregnant women }(P=0.06)] \text {. }\end{array}$ \\
\hline Tsega et al. ${ }^{27}$ 1993-Ethiopia & $\begin{array}{l}19(59 \%) \text { of } 34 \text { pregnant } \\
\text { women had HEV infection }\end{array}$ & $\begin{array}{l}\text { FHF } \\
\text { Premature deliveries as a } \\
\text { direct result of acute viral } \\
\text { hepatitis }\end{array}$ & Maternal death with FHF \\
\hline $\begin{array}{l}\text { Kumar et al. }{ }^{36} 2001 \text {-United } \\
\text { Arab Emirates }\end{array}$ & $\begin{array}{l}\text { Out of } 469 \text { mothers, } 93(20 \%) \\
\text { were anti-HEV positive and } 28 \\
\text { ( } 30 \%) \text { were HEV-RNA positive } \\
\text { and symptomatic with } \\
\text { on-going infection. }\end{array}$ & $\begin{array}{l}\text { FHF, non-fulminant acute } \\
\text { viral hepatitis }\end{array}$ & Fetal outcomes with FHF \\
\hline Rayis et al., ${ }^{41}$ 2013-Sudan & $\begin{array}{l}38 \text { pregnant women with } \\
\text { outbreaks }\end{array}$ & $\begin{array}{l}\text { FHF, post partum hemorrhage, } \\
\text { intrauterine fetal death }\end{array}$ & $\begin{array}{l}\text { Maternal deaths due FHF with } \\
\text { hepatic encephalopathy was the } \\
\text { most common cause of death } \\
\text { among these patients. }\end{array}$ \\
\hline Zaki et al., ${ }^{38} 2013$-Egypt & HEV IgG $(31 \%)$ in 29 & Mild hepatic disorders & No death \\
\hline
\end{tabular}

Table 2. Vertical transmission of HEV from infected mother to neonates and its consequences

\begin{tabular}{|c|c|c|}
\hline & $\begin{array}{l}\text { Consequences of vertical hepatitis } \mathrm{E} \\
\text { transmission }\end{array}$ & $\begin{array}{l}\text { Frequency of transmission from affected } \\
\text { mother to neonate }\end{array}$ \\
\hline Kumar et al., ${ }^{36} 2001$ & $\begin{array}{l}\text { Acute viral hepatitis with complete recov- } \\
\text { ery, limited early neonatal deaths }\end{array}$ & $100 \%$ \\
\hline Kumar et al., ${ }^{37} 2004$ & Preterm birth & $33 \%$ \\
\hline Zaki et al., 2013 & $\begin{array}{l}\text { Respiratory distress syndrome } \\
\text { preterm birth } \\
\text { sepsis } \\
\text { Hepatosplenomegaly }\end{array}$ & $33 \%$ \\
\hline Khuroo et al., ${ }^{39} 2009$ & $\begin{array}{l}\text { icteric hepatitis, } \\
\text { anicteric hepatitis, and } \\
\text { neonatal death } \\
\text { All surviving babies had self-limiting dis- } \\
\text { ease and none had prolonged viremia. }\end{array}$ & $79 \%$ \\
\hline Khuroo et al., ${ }^{21} 1995$ & $\begin{array}{l}\text { Icteric neonatal hepatitis, } \\
\text { non icteric neonatal hepatitis, } \\
\text { hypothermia, and hypoglycaemia and died } \\
\text { within } 24 \text { h; } \\
\text { massive hepatic necrosis. }\end{array}$ & - \\
\hline Patra et al., 232007 & $\begin{array}{l}\text { Intrauterine fetal death } \\
\text { Still birth } \\
\text { Preterm }\end{array}$ & - \\
\hline Rayis et al., ${ }^{41} 2013$ & $\begin{array}{l}\text { Intrauterine fetal death } \\
\text { Preterm }\end{array}$ & - \\
\hline
\end{tabular}




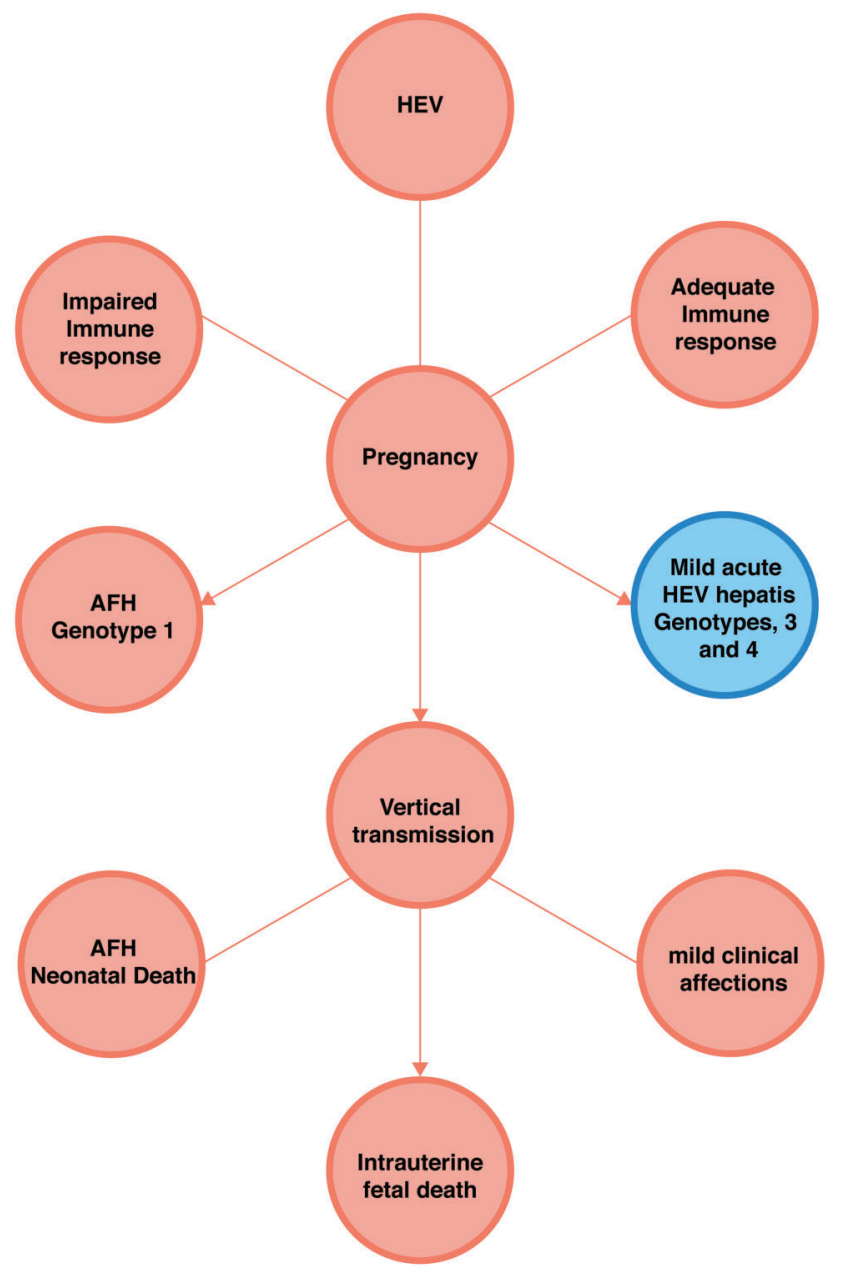

Fig. 1. Effects of HEV infection in pregnancy the virological markers and clinical symptoms in the weeks after infection. This figure is a modification of one from the Center for Disease Control (CDC).

Several commercial assays are available internationally; however, no assay is currently approved by the US Food and Drug Administration (FDA). In addition to serological assays, nucleic acid amplification methods can be used to identify HEV RNA both in the blood and stool of infected individuals. In a human volunteer experiment, HEV RNA was detectable in blood at the apex of eccentric liver function tests starting from two weeks before and up to one week after onset of jaundice. HEV RNA appeared in stool later than in blood and vanished from stool within two weeks after it became undetectable in blood. ${ }^{72}$ Fig. 3 summarizes laboratory procedures used in the diagnosis of HEV.

\section{HEV therapeutic modalities}

To date, there are no efficient treatments for hepatitis $E$ in pregnancy. Experimental use of ribavirin to treat acute hepatitis has promising results in non-pregnant patients, ${ }^{73-}$ 75 but unfortunately, this drug is contraindicated in pregnancy because of consequential embryocidal and/or teratogeniceffects. ${ }^{76}$ Several researchers have suggested that early induced distribution or even pregnancy termination may be considered to preserve the life of the mother. ${ }^{54,77}$ However, this line of treatment to avert death in women who present with astringent disease has not been studied systematically. Given the high rate of miscarriage, stillbirth, and premature distribution in pregnancies affected by astringent hepatitis $E$, the net impact of such a strategy on neonatal morbidity and mortality is questionable.

\section{HEV aversion and control strategies}

Aversion measures typically involve amelioration of unsanitary conditions and provision of safe to drink water. Efforts to reduce person-to-person transmission of HEV needs to focus on hand

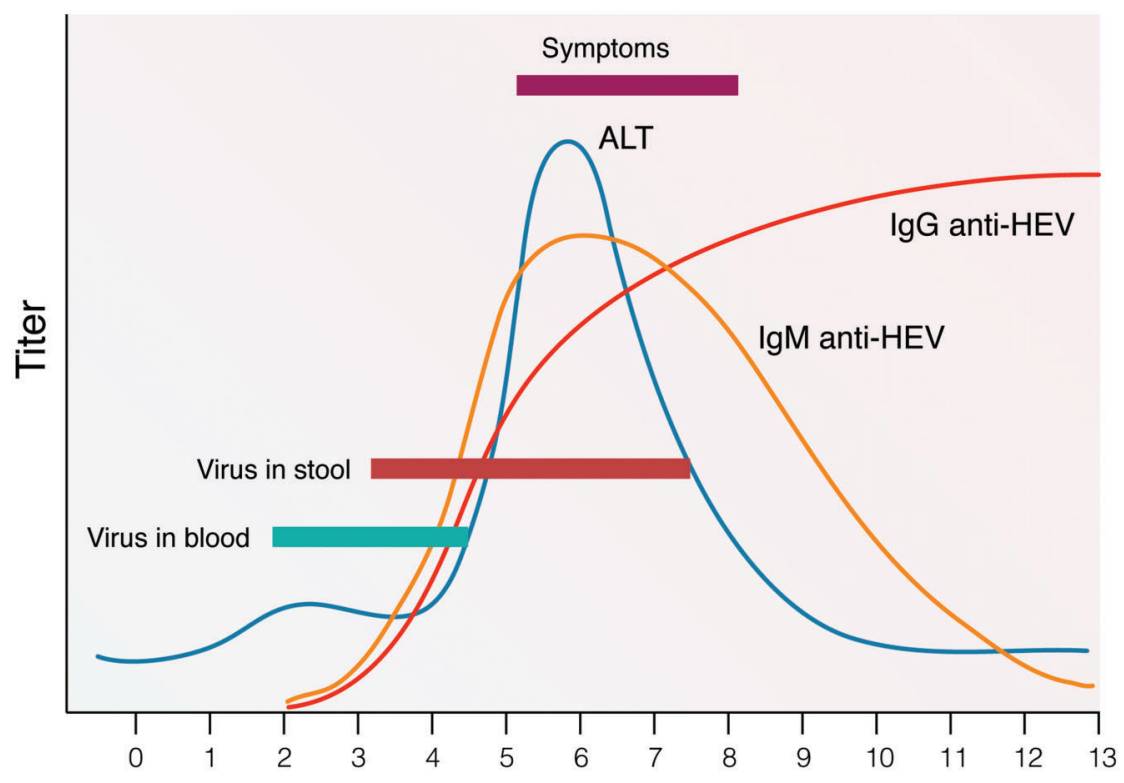

Fig. 2. Appearance of virological markers and symptoms of HEV infection according to weeks after infection. 


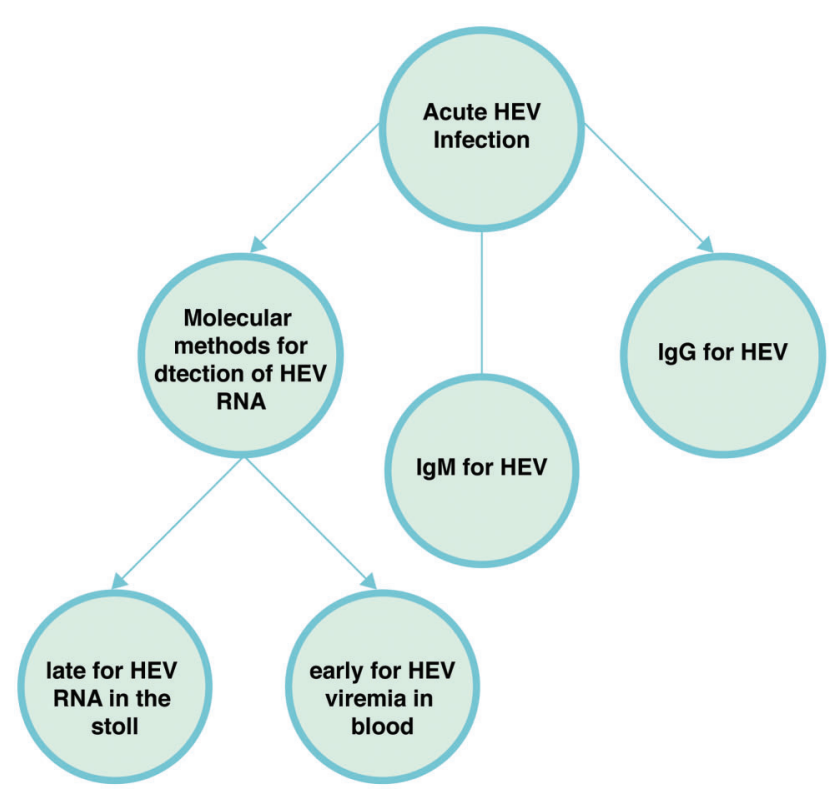

Fig. 3. Laboratory diagnosis of HEV

washing. According to CDC regulations, in order to prevent infections when visiting endemic areas, the safe drinking water will be sealed carbonated water or water disinfected by boiling, filtration, or treatment by other methods.

Because the prosperity of current therapeutic modalities is limited, there is an exigent need to develop and provide a reliable efficacious hepatitis $E$ vaccine. ${ }^{78}$ Albeit at least one HEV vaccine candidate has shown promise in clinical trials, none has been approved by the FDA or any international regulatory agency.

Recently developed HEV vaccines have shown good results in averting hepatitis $E_{1}^{79,80}$ and they may avail to decrease the necessity for treating rigorous illness. Nevertheless, future data will determine if HEV infections can still occur in efficiently vaccinated adults. ${ }^{81}$ There is very limited data available regarding safety and efficacy in pregnant women for the vaccine. ${ }^{82}$ Future studies are necessary to evaluate the efficacy of these vaccines in averting maternal disease and death and reducing fetal loss, premature distribution, and neonatal morbidity and mortality. ${ }^{34}$ Such research should be a global maternal child health priority and will perhaps inspire the development of further vaccines and eventual implementation in susceptible populations.

\section{Conclusions}

From this article we can conclude that HEV represent a health problem during pregnancy for both mother and fetus. Different outcomes of pregnancy associated with HEV depend upon several factors. The spectrum of the disease and its outcome needs extended studies to know the missing parts of the puzzle.

\section{Conflict of interest}

None

\section{Author contributions}

Conception and designing of the article, acquisition of data, analysis and interpretation of data (MESZ); drafting the article or revising (MMAER, $H, A E R$ ).

\section{References}

[1] Lu L, Li C, Hagedorn CH. Phylogenetic analysis of global hepatitis E virus sequences: genetic diversity, subtypes and zoonosis. Rev Med Virol 2006 ; 16:5-36. doi: 10.1002/rmv.482.

[2] Panda SK1, Nanda SK, Zafrullah M, Ansari IH, Ozdener MH, Jameel S. An Indian strain of hepatitis $\mathrm{E}$ virus (HEV) : cloning, sequence, and expression of structural region and antibody responses in sera from individuals from an area of high- level HEV endemicity. J Clin Microbiol 1995;33:2653-2659.

[3] Tam AW, Smith MM, Guerra ME, Huang CC, Bradley DW, Fry KE, et al. Hepatitis E virus (HEV) : molecular cloning and sequencing of the full-length viral genome. Virology 1991;185:120-131. doi: 10.1016/00426822(91)90760-9.

[4] Aye TT, Uchida $T$, Ma X, Iida $F$, Shikata $T$, Zhuang $H$, et al. Sequence comparison of the capsid region of hepatitis $E$ viruses isolated from Myanmar and China. Microbiol Immunol 1992;36:615-621. doi: 10.1111/j.13480421.1992.tb02061.x.

[5] Bi SL, Purdy MA, McCaustland KA, Margolis HS, Bradley DW. The sequence of hepatitis $E$ virus isolated directly from a single source during an outbreak in China. Virus Res 1993;28:233-247. doi: 10.1016/0168-1702(93)90024-H.

[6] Tsarev SA, Emerson SU, Reyes GR, Tsareva TS, Legters LJ, Malik IA, et al. Characterization of a prototype strain of hepatitis E virus. Proc Natl Acad Sci U S A 1992;89:559-563. doi: 10.1073/pnas.89.2.559.

[7] van Cuyck-Gandré H, Zhang HY, Tsarev SA, Warren RL, Caudill JD, Snellings $\mathrm{NJ}$, et al. Short report : phylogenetically distinct hepatitis $\mathrm{E}$ viruses in Pakistan. Am J Trop Med Hyg 2000;62:187-189.

[8] Gouvea V, Snellings N, Popek MJ, Longer CF, Innis BL. Hepatitis E virus : complete genome sequence and phylogenetic analysis of a Nepali isolate. Virus Res 1998;57:21-26. doi: 10.1016/S0168-1702(98)00079-3.

[9] van Cuyck-Gandré H, Zhang HY, Tsarev SA, Clements NJ, Cohen SJ, Caudill JD, et al. Characterization of hepatitis E virus (HEV) from Algeria and Chad by partial genome sequence. J Med Virol 1997;53:340-347. doi: 10.1002/ (SICI)1096-9071(199712)53:4<340::AID-JMV5>3.0.CO;2-7.

[10] Chatterjee R, Tsarev S, Pillot J, Coursaget P, Emerson SU, Purcell RH. African strains of hepatitis $E$ virus that are distinct from Asian strains. J Med Viro 1997;53:139-144. doi: 10.1002/(SICI)1096-9071(199710)53:2<139: AID-JMV5 > 3.0.CO;2-A.

[11] Tsarev SA, Binn LN, Gomatos PJ, Arthur RR, Monier MK, van Cuyck-Gandre H, et al. Phylogenetic analysis of hepatitis $\mathrm{E}$ virus isolates from Egypt. J Med Virol 1999;57:68-74. doi: 10.1002/(SICI)1096-9071(199901)57: $1<68$ ::AID-JMV10>3.0.CO;2-E.

[12] He J, Binn LN, Tsarev SA, Hayes CG, Frean JA, Isaacson M, et al. Molecular characterization of a hepatitis E virus isolate from Namibia. J Biomed Sci 2000;7:334-338. doi: 10.1007/BF02253253

[13] Takahashi M, Nishizawa T, Yoshikawa A, Sato S, Isoda N, Ido K, et al. Identification of two distinct genotypes of hepatitis $\mathrm{E}$ virus in a Japanese patient with acute hepatitis who had not travelled abroad. J Gen Virol 2002 ; 83:1931-1940

[14] Schlauder GG, Desai SM, Zanetti AR, Tassopoulos NC, Mushahwar IK. Novel hepatitis E virus (HEV) isolates from Europe: evidence for additional genotypes of HEV. J Med Virol 1999;57:243-251. doi: 10.1002/(SICI)10969071(199903)57:3<243: :AID-JMV6>3.0.CO;2-R.

[15] Buisson $Y$, Grandadam M, Nicand E, Cheval $P$, van Cuyck-Gandre H, Innis B, et al. Identification of a novel hepatitis E virus in Nigeria. J Gen Virol 2000; 81:903-909.

[16] Zanetti AR, Schlauder GG, Romanò L, Tanzi E, Fabris P, Dawson GJ, et al. Identification of a novel variant of hepatitis E virus in Italy. J Med Virol 1999; 57:356-360. doi: 10.1002/(SICI)1096-9071(199904)57:4<356: :AIDJMV5>3.0.CO;2-D.

[17] Chandra V, Taneja S, Kalia M, Jameel S. Molecular biology and pathogenesis of hepatitis E virus. J Biosci 2008;33:451-464.

[18] Hyams KC. New perspectives on hepatitis E. Curr Gastroenterol Rep 2002;4: 302-307. doi: 10.1007/s11894-002-0080-5.

[19] Khuroo MS. Study of an epidemic of non-A, non-B hepatitis: possibility of another human hepatitis virus distinct from posttransfusion non- $A$, nonBtype. Am J Med 1980;68:818-824.

[20] Bednar M, Frankova V, Schindler J, Soucek A, Vavra J. Medical Microbiology (in Czech). 1999, 1st ed. (Reissue), Nakladatelstvi Marvil, Prague. 558 pp.

[21] Khuroo MS, Kamili S, Jameel S. Vertical transmission of hepatitis E virus. Lancet 1995;345:1025-1026. doi: 10.1016/S0140-6736(95)90761-0. 
[22] Kumar Acharya S, Kumar Sharma P, Singh R, Kumar Mohanty S, Madan K, Kumar Jha J, et al. Hepatitis E virus (HEV) infection in patients with cirrhosis is associated with rapid decompensation and death. J Hepatol 2007;46:387394. doi: 10.1016/j.jhep.2006.09.016.

[23] Patra S, Kumar A, Trivedi SS, Puri M, Sarin SK. Maternal and fetal outcomes in pregnant women with acute hepatitis $E$ virus infection. Ann Intern Med 2007;147:28-33. doi: 10.7326/0003-4819-147-1-200707030-00005.

[24] Navaneethan U, Al Mohajer M, Shata MT. Hepatitis E and pregnancy: understanding the pathogenesis. Liver Int 2008;28:1190-1199. doi: 10.1111/j.1478-3231.2008.01840.x.

[25] Khuroo MS, Teli MR, Skidmore S, Sofi MA, Khuroo MI. Incidence and severity of viral hepatitis in pregnancy. Am J Med 1981;70:252-255.

[26] Purcell, R H. \& Emerson, S. U. (2001). Hepatitis E virus. In: D.M. Knipe \& P. M. Howley, editors. Fields Virology, 4th edition, Philadelphia: Lippincott Williams \& Wilkins; 2001;3051-3061.

[27] Tsega E1, Krawczynski K, Hansson BG, Nordenfelt E. Hepatitis E virus infection in pregnancy in Ethiopia. Ethiop Med J 1993;31:173-81.

[28] Pradhan M, Anand B, Singh A. Hepatitis E virus infection causing isolated fetal ascites: a case report. Fetal Diagn Ther 2012;32:292-294. doi: 10.1159/ 000337612.

[29] Siebenlist U, Franzoso G, Brown K. Structure, regulation and function of NFkappa B. Ann Rev Cell Biol 1994;10:405-55. doi: 10.1146/annurev.cb.10.110194.002201.

[30] Kar P. Hepatitis E Virus Infection During Pregnancy: Why Is The Disease Stormy? Medicine Update 2012;22:459-462.

[31] Stoszek SK1, Abdel-Hamid M, Saleh DA, El Kafrawy S, Narooz S, Hawash Y, et al. High prevalence of hepatitis $\mathrm{E}$ antibodies in pregnant Egyptian women. Trans R Soc Trop Med Hyg 2006;100:95-101. doi: 10.1016/j.trstmh. 2004.12.005.

[32] Stoszek SK, Engle RE, Abdel-Hamid M, Mikhail N, Abdel-Aziz F, Medhat A, et al. Hepatitis $E$ antibody seroconversion without disease in highly endemic rural Egyptian communities. Trans R Soc Trop Med Hyg 2006;100:89-94. doi: 10.1016/j.trstmh.2005.05.019.

[33] Merle P, Zoulin F, Trepo C. Hepatitis B virus infection. Hepatology - A Practical Approach. San Diego: Elsevier Academic press, 2004:67-86.

[34] Kamili S. Immunity to hepatitis E virus: new insights and future challenges. Ind J Gastroenterol 2002;21:136-138.

[35] Krain LJ1, Atwell JE, Nelson KE, Labrique AB. Mother to child transmission of hepatitis $\mathrm{E}$ virus fetal and neonatal health consequences of vertically transmitted hepatitis E virus infection. Am J Trop Med Hyg 2014;90:36570. doi: 10.4269/ajtmh.13-0265.

[36] Kumar RM, Uduman S, Rana S, Kochiyil JK, Usmani A, Thomas L. Seroprevalence and mother-to-infant transmission of hepatitis $\mathrm{E}$ virus among pregnant women in the United Arab Emirates. Eur J Obstet Gynecol Reprod Biol 2001;100:9-15. doi: 10.1016/S0301-2115(01)00448-1.

[37] Kumar A1, Beniwal M, Kar P, Sharma JB, Murthy NS. Hepatitis E in pregnancy. Int J Gynaecol Obstet 2004;85:240-244. doi: 10.1016/j.ijgo.2003.11.018.

[38] El Sayed Zaki M, El Aal AA, Badawy A, El-Deeb DR, El-Kheir NY. Clinicolaboratory Study of Mother-to-Neonate Transmission of Hepatitis E Virus in Egypt. Am J Clin Pathol 2013;140:721-726. doi: 10.1309/ AJCPT55TDMJNPLLV.

[39] Khuroo MS, Kamili S. Clinical course and duration of viremia in vertically transmitted hepatitis $\mathrm{E}$ virus (HEV) infection in babies born to HEV-infected mothers. J Viral Hepat 2009;16:519-523. doi: 10.1111/j.13652893.2009.01101.x

[40] Aggarwal R. Clinical presentation of hepatitis E. Virus Res 2011;161:15-22. doi: 10.1016/j.virusres.2011.03.017.

[41] Rayis DA, Jumaa AM, Gasim GI, Karsany MS, Adam I. An outbreak of hepatitis $\mathrm{E}$ and high maternal mortality at Port Sudan, Eastern Sudan. Pathog Glob Health 2013;107:66-68. doi: 10.1179/2047773213Y.0000000076.

[42] Maila HT, Bowyer SM, Swanepoel R. Identification of a new strain of hepatitis E virus from an outbreak in Namibia in 1995. J Gen Virol 2004;85:89-95. doi: 10.1099/vir.0.19587-0.

[43] Goldenberg RL, Thompson C. The infectious origins of stillbirth. Am J Obstet Gynecol 2003;189:861-873. doi: 10.1067/S0002-9378(03)00470-8.

[44] Goldenberg RL, McClure EM, Saleem S, Reddy UM. Infection-related stillbirths. Lancet $2010 ; 375: 1482-1490$. doi: $10.1016 /$ S01406736(09)61712-8.

[45] Kelley M, Rubens CE, GAPPS Review Group. Global report on preterm birth and stillbirth ( 6 of 7 ): ethical considerations. BMC Pregnancy Childbirth 2010;10 (Suppl 1):S6. doi: 10.1186/1471-2393-10-S1-S6.

[46] Lawn JE, Blencowe H, Pattinson R, Cousens S, Kumar R, Ibiebele I, et al. Stillbirths: where? when? why? How to make the data count? Lancet 2011; 377:1448-1463. doi: 10.1016/S0140-6736(10)62187-3.

[47] Zhai Q, Zhang LF, Liang RM, Zhang YH, Sun SY, Cao XY. Immunohistochemical study of hepatitis $E$ virus antigen in liver tissues from patients with hepatitis E. Chin Med J (Engl) 1994;107:222-224.

[48] El-Esnawy NA, Ali MA, Bayoumi FS, Abo-El-Khir A, Abdel-Wahab KS. Waterborne viruses associated with repeated abortion. J Egypt Public Health Assoc 2001;76:487-503.
[49] Tsarev SA, Tsareva TS, Emerson SU, Rippy MK, Zack $P$, Shapiro M, et al. Experimental hepatitis $E$ in pregnant rhesus monkeys: failure to transmit hepatitis E virus (HEV) to offspring and evidence of naturally acquired antibodies to HEV. J Infect Dis 1995;172:31-37. doi: 10.1093/infdis/ 172.1.31.

[50] Arankalle VA, Chadha MS, Banerjee K, Srinivasan MA, Chobe LP. Hepatitis E virus infection in pregnant rhesus monkeys. Indian J Med Res 1993;97:4-8.

[51] Kasorndorkbua C, Thacker B], Halbur PG, Guenette DK, Buitenwerf RM, Royer $\mathrm{RL}$, et al. Experimental infection of pregnant gilts with swine hepatitis $\mathrm{E}$ virus. Can J Vet Res 2003;67:303-306.

[52] Krawczynski K, Meng X], Rybczynska J, Pathogenetic elements of hepatitis E and animal models of HEV infection. Virus Res 2011;161:78-83. doi: $10.1016 / j$.virusres.2011.03.007.

[53] Hosmillo M, Jeong Y], Kim HJ, Park JG, Nayak MK, Alfajaro MM, et al. Molecular detection of genotype 3 porcine hepatitis $E$ virus in aborted fetuses and their sows. Arch Virol 2010;155:1157-1161. doi: 10.1007/s00705-010-0679-z.

[54] Khuroo MS, Kamili S, Jameel S. Vertical transmission of hepatitis E virus. Lancet 1995;345:1025-1026. doi: 10.1016/S0140-6736(95)90761-0.

[55] Khuroo MS,. Association of severity of hepatitis E virus infection in the mother and vertically transmitted infection in the fetus. JK Pract 2006;13:70-74.

[56] Kumar A, Beniwal M, Kar P, Sharma JB, Murthy NS. Hepatitis E in pregnancy. Int J Gynaecol Obstet 2004;85:240-244.

[57] Dahiya M, Kumar A, Kar P, Gupta RK. Acute viral hepatitis in third trimester of pregnancy. Indian J Gastroenterol 2005;24:128-129.

[58] Nelson KE, Kmush B, Labrique AB. The epidemiology of hepatitis E virus infections in developed countries and among immunocompromised patients. Expert Rev Anti Infect Ther 2011;9:1133-1148. doi: 10.1586/eri.11.138.

[59] Jaiswal SB, Chitnis DS, Asolkar MV, Naik G, Artwani KK. Aetiology and prognostic factors in hepatic failure in central India. Trop Gastroenterol $1996 ; 17: 217-220$.

[60] Jaiswal SP, Jain AK, Naik G, Soni N, Chitnis DS. Viral hepatitis during pregnancy. Int J Gynaecol Obstet 2001;72:103-108.

[61] Jilani N, Das BC, Husain SA, Baweja UK, Chattopadhya D, Gupta RK, et al. Hepatitis $E$ virus infection and fulminant hepatic failure during pregnancy. J Gastroenterol Hepatol 2007;22:676-682. doi: 10.1111/j.14401746.2007.04913.x

[62] Kar P, Jilani N, Husain SA, Pasha ST, Anand R, Rai A, et al. Does hepatitis E viral load and genotypes influence the final outcome of acute liver failure during pregnancy? Am J Gastroenterol 2008;103:2495-2501.

[63] Strand RT, Franque-Ranque M, Bergstrom S, Weiland O. Infectious aetiology of jaundice among pregnant women in Angola. Scand J Infect Dis 2003;35: 401-403.

[64] Tsega E, Krawczynski K, Hansson BG, Nordenfelt E. Hepatitis E virus infection in pregnancy in Ethiopia. Ethiop Med J 1993;31:173-181.

[65] Kumar A, Beniwal M, Kar P, Sharma JB, Murthy NS. Hepatitis E in pregnancy. Int J Gynaecol Obstet 2004;85:240-244.

[66] Singh S, Mohanty A, Joshi YK, Deka D, Mohanty S, Panda SK. Mother-to-child transmission of hepatitis E virus infection. Indian J Pediatr 2003;70:37-39.

[67] Dalton HR, Bendall RP, Keane FE, Tedder RS, Ijaz S. Persistent carriage of hepatitis E virus in patients with HIV infection. N Engl J Med 2009;361:10251027.

[68] Cardenas I, Means RE, Aldo P, Koga K, Lang SM, Booth C], et al. Viral infection of the placenta leads to fetal inflammation and sensitization to bacterial products predisposing to preterm labor. J Immunol 2010;185:1248-1257. doi: $10.4049 /$ jimmunol.1000289.

[69] Cardenas I, Mor G, Aldo P, Lang SM, Stabach P, Sharp A, et al. Placental viral infection sensitizes to endotoxin-induced pre-term labor: a double hit hypothesis. Am J Reprod Immunol 2011;65:110-117.

[70] Bose PD, Das BC, Kumar A, Gondal R, Kumar D, Kar P. High viral load and deregulation of the progesterone receptor signaling pathway: association with hepatitis E-related poor pregnancy outcome. J Hepatol 2011;54:11071113. doi: 10.1016/j.jhep.2010.08.037.

[71] Favorov MO1, Fields HA, Purdy MA, Yashina TL, Aleksandrov AG, Alter MJ, et al Serologic identification of hepatitis $\mathrm{E}$ virus in epidemic and endemic settings. J Med Virol 1992;36:246-250. doi: 10.1002/jmv.1890360403.

[72] Chadha MS, Walimbe AM, Arankalle VA. Retrospective serological analysis of hepatitis E patients: a long-term follow-up study. J Viral Hepat 1999;6:457461. doi: 10.1046/j.1365-2893.1999.00190.x.

[73] Chauhan A1, Jameel S, Dilawari JB, Chawla YK, Kaur U, Ganguly NK. Hepatitis E virus transmission to a volunteer. Lancet 1993;341:149-150. doi: 10.1016/0140-6736(93)90008-5.

[74] Gerolami R, Borentain P, Raissouni F, Motte A, Solas C, Colson P. Treatment of severe acute hepatitis E by ribavirin. J Clin Virol 2011;52:60-62. doi: $10.1016 / j . j c v .2011 .06 .004$.

[75] Karim F, Rahman S, Al-Mahtab M, Ahmed F. Successful treatment of severe hepatitis E with ribavirin: a case report from Bangladesh. Euroasian J Hepato-Gastroenterol 2012;2:56-57.

[76] Pischke S, Hardtke S, Bode U, Birkner S, Chatzikyrkou C, Kauffmann W, et al. Ribavirin treatment of acute and chronic hepatitis E: a single-centre experience. Liver Int 2013;33:722-726. doi: 10.1111/liv.12114. 
Zaki M.E. et al.: Hepatitis E, pregnancy

[77] State of Florida Department of Health Central Pharmacy, 2010. National Library of Medicine (NLM) DailyMed Database, 2010.

[78] Navaneethan U, Al Mohajer M, Shata MT. Hepatitis E and pregnancy: understanding the pathogenesis. Liver Int 2008;28:1190-1199. doi: 10.1111/j.1478-3231.2008.01840.x.

[79] Krawczynski K. Hepatitis E vaccine-ready for prime time? N Engl ] Med 2007; 356:949-951

[80] Shrestha MP, Scott RM, Joshi DM, Mammen MP Jr, Thapa GB, Thapa N, et al. Safety and efficacy of a recombinant hepatitis E vaccine. N Engl J Med 2007; 356:895-903.
[81] Zhu FC, Zhang J, Zhang XF, Zhou C, Wang ZZ, Huang SJ, et al. Efficacy and safety of a recombinant hepatitis $E$ vaccine in healthy adults: a large-scale, randomised, double-blind placebo-controlled, phase 3 trial. Lancet 2010 376:895-902. doi: 10.1016/S0140-6736(10)61030-6.

[82] Zhang J, Zhang XF, Zhou C, Wang ZZ, Huang SJ, Yao X, et al. Protection against hepatitis $E$ virus infection by naturally aquired and vaccine incude immunity. Clin Microbiol Infect, 2013 Oct.

[83] Wu T, Zhu FC, Huang SJ, Zhang XF, Wang ZZ, Zhang J, et al. Safety of the hepatitis $E$ vaccine for pregnant women: a preliminary analysis. Hepatology 2012;55:2038. doi: 10.1002/hep.25522. 